\title{
VOLKSTELLINGEN IN SURINAME
}

\author{
DOOR
}

FRED. OUDSCHANS DENTZ

Er zijn in Suriname drie volkstellingen gehouden, in 1694, in 1811 en in 1921 .

De eerste volkstelling had in Januari 1694 1) plaats. In de politieke notulen van 14 Mei 1696-9 October 1700 lezen wij: Modique lasten voor de Colonie van Suriname Credit p. saldo tot dato deser, 31 Dec. 1696, volgens uijtwijs hierboven lbs 303900 (suiker),

p. taxatie op de consumtie der Inlantse vruchten ofte vivres (gecalculeert volgens de opnemingen van Jan. 1694 als wanneer bevonden wierde 6423 zoo blancke menschen als slaven) à 45 st. per Hooft lb 289035 (suiker), het pond berekend tegen 5 cent.

De tweede volkstelling had in 1811 tijdens het Engelsche tusschenbestuur plaats. Dat daar aan veel zorg besteed werd, blijkt wel uit het aantal van 16 foliodeelen, welke in de State Paper Office te Londen aanwezig zijn.

Deze volkstelling, door gouverneur Bentinck bevolen, geschiedde op 17 October $1811^{2}$ ) onder gouverneur Bonham. Het resultaat was, dat er 5104 vrijen en 50.725 slaven werden geteld. Van die 5.104 vrijen waren nu 2.029 blanken en Joden en 2.980 vrije kleurlingen en negers (christenen zoowel als heidenen), tezamen 55.829 zielen (militairen niet medegerekend) ${ }^{3}$ ).

De derde volkstelling had in 1921 plaats in verband met de invoering van het bevolkingsregister in Suriname. De opneming geschiedde des middernachts 31 Juli. De uitkomst was als volgt: bevolking 107.723, waarvan 56.177 van het mannelijk en 51.546 van het vrouwelijk geslacht (Boschnegers en Indianen uitgezon-

1) Politieke Notulen 9 Januari 1694, blz. 220.

2) Alsvoren 17 October 1811.

3) Brief van gouverneur Bonham aan Earl Liverpool van 30 Maart 1812. Zie Wolbers, blz. 565. 
192 FRED. OUDSCHANS DENTZ, VOLKSTELLINGEN IN SURINAME

derd). Er werden 12.552 woonhuizen, 17.491 kamers ${ }^{1}$ ) en 9.495 hutten geteld.

Behalve de voorgaande zijn er enkele gedetailleerde opgaven van bevolking bekend nl. een van 1738 (de oudste) door B. van der Oudermeulen, welke aangeeft, 1.731 2) blanken en 51.096 slaven, tezamen 52.827. Een schatting van 1787 gaf aan blanken in Paramaribo 2.000 (waaronder 1.045 Joden), 650 vrijen en 7.000 slaven, tezamen 9.650 en voor de districten 3.356 blanken en 50.000 slaven. Totale bevolking 63.006 (zonder de militairen, Boschnegers en Indianen).

Volgens het laatste jaarverslag van 1938, bestond de bevolking uit 150.896 zielen, waarvan 2.000 Europeanen (1.005 in Nederland en 995 elders geboren), 67.749 inboorlingen, 31.930 NederlandschIndiërs, 43. 844 Britsch-Indiërs, 2. 159 Chineezen en 3.214 anderen. De Boschnegers en Indianen werden onderscheidenlijk op 17.000 en 3.500 geschat, zoodat de totale bevolking 171.396 bedroeg, waarvan er in Paramaribo 52.368 woonden, dat is $30,5 \%$ van de geheele bevolking.

1) Onder kamers verstaat men de gebouwen op het erf.

2) Blz. 665 van de Encyclopedie van Ned. W. I. vermeldt abusievelijk 1738 inplaats van 1731. In den tabel daaronder zijn de jaren 1811 en 1815 verwisseld. 